\title{
Physiological Responses and Blood Profile of Broiler Chicken Supplemented with Red Dragon Fruit Peel (Hylocereus polyrhizus) Subjected to Transportation Stress
}

\author{
Nurmeiliasari, Yosi Fenita, Een Zitriyani, Fitrianti Firdaus \\ Animal Science Departement, Faculty of Agriculture, University of Bengkulu, \\ Bengkulu Indonesia 38371 \\ Corresponding author: sari_nurmeiliasari@unib.ac.id
}

\begin{abstract}
Measurements on physiological responses and blood profile in 60 broiler chickens were conducted to evaluate the effect of red dragon fruit peel supplementations against three-hour road transportation stress. Broiler chickens aged 35 days were distributed into four treatment groups based on levels of red dragon fruit peel supplementation ( $0 \mathrm{~g}$ per head; $2.43 \mathrm{~g}$ per head; $3.64 \mathrm{~g}$ per head and $4.86 \mathrm{~g} / \mathrm{head})$. The birds were loaded into plastic crates and transported for three hours. After a - three hour road transportation, the chickens were unloaded to measure respiration rate, rectal temperature and body weight loss. Blood samples were collected for changes in selected hematological parameters. Respiration rates and rectal temperatures were monitored before and after transportation process. The broilers were weighed before and after transportation. During transportation, the temperature and humidity were ranging from $33,55-35,6^{\circ} \mathrm{C}$ and $60,25-64 \%$, respectively. There were no significant effects of dragon fruit peel supplementation on physiological responses and weight loss. The number of leukocytes and erythrocytes were not different from those of control broilers. Similarly, levels of hemoglobin and hematocrit values were not affected by supplementation of red dragon fruit peel. Measurements of leukocyte differentiation showed insignificant different; thus, the supplementation did not affect ratio of heterophyl: lymphocyte of broilers. In conclusion, supplementation of dragon fruit peel did not affect physiological responses and blood profile of broiler chicken subjected to transportation stress.
\end{abstract}

Key words: broiler chicken, red dragon fruit peel, transportation, physiological response, blood profile

\section{INTRODUCTION}

Broiler chicken's transportation aims to distribute live animals from the farm to the slaughterhouses. This activity has negative effects that result in an economic loss for poultry producers. Genetic and environmental factors determine the susceptibility of broilers to stress. Broiler chickens are susceptible to stress because during land transportation, the chickens are exposed to thermal changes, acceleration, noise, motion, vibration, fasting, withdrawal of water, social disruption etc. Stress conditions alter the physiological and biochemical status of broiler chickens [1]. Stressors during transportations are varied and complex. The transportation stressors are mental, physical or mixed stressors [2]. Transportation increases physical and mental stress on birds. Physical stressors such as water deprivation and feed withdrawal during transportation are stressors that lead to decreases in body weight [3]. Mortality of broilers is attributable to climate stressors and crating density [4].

Heat stress occurs when the ambient temperature changes to a higher temperature above the comfort zone, the comfortable temperature in chickens is $18-22^{\circ} \mathrm{C}$. In this condition, the tolerance of livestock to the environment becomes low or decreases. Body temperature of broilers during transportation generally increases by $1{ }^{\circ} \mathrm{C}$ [5]. Heat stress affects glucocorticoid hormones in the body that reduce body immunity. High heat stress causes a decrease in the number of lymphocytes and an increase in the number of heterophils in the blood resulting in an increase in the heterophil and lymphocyte ratio [6].

Antioxidant-rich fruits are able to reduce stress. According to research by Nurliyana et al. [7] super red dragon fruit peel is rich in polyphenols and a good source of antioxidants. Choo and Yong [8] mentioned that dragon fruit skin is rich in vitamin $\mathrm{C}$, vitamin $\mathrm{E}$, vitamin A, alkaloids, terpenoids, flavonoids, thiamine, niacin, pyridoxine, cobalamin, phenolic, carotene, and phytoalbumin. This study aimed to evaluate physiological responses and blood profile of broiler chicken supplemented with dragon fruit peel subjected to transportation stress. 


\section{MATERIALS AND METHODS}

Sixty broiler chickens aged 35 days with a body weight of $1.6-1.8 \mathrm{~kg}$ were used. This study used 4 treatments and 15 replications, and the treatments given were as follows.

P0 : control

$\mathrm{P} 1$ : 2,43 g/ head red dragon fruit peel flour dissolved into $10 \mathrm{ml}$ of drinking water

P2 : 3,64 g/ head red dragon fruit peel flour dissolved into $10 \mathrm{ml}$ of drinking water

P3 : 4,86 g/ red head red dragon fruit peel flour dissolved into $10 \mathrm{ml}$ of drinking water.

The dietary withdrawal was conducted 8 hours prior the transportation, and the drinking water restriction was conducted 2 hours before transportation. Then the broiler chickens were weighed using digital scales prior departure. The broiler chickens were loaded into the vehicle, and transportation study was performed for 180 minutes started from 10.00 am to $13.00 \mathrm{pm}$. The average local temperature was $30^{\circ} \mathrm{C}$, and humidity was $39.5 \%$. Temperature and humidity were measured at first, second and third hour of the transportation process using a digital thermohygrometer. Immediately following the transportation, the chickens were unloaded and measured for parameters listed below.

\subsection{Body Weight Loss, Physiological Responses and Mortality \\ The broiler chickens were weighed upon} arrival. Total weight loss was calculated. The rectal temperature was obtained by inserting a digital thermometer into the bird's rectum, until the reading is stable. Respiration rate was measured by counting the number of painting breaths for 60 seconds. Percentage of Death On Arrival (DOA\%) describes the cumulative deaths that happened between the time of loading and the time of arrival at the processing plant.

\subsection{Blood sampling and hematology measurements.}

Blood sampling was drawn from the brachial wing vein, which is located between the bicep and tricep at the underside of the wing by using $6 \mathrm{~mL}$ syringe. Ethylene Diamine Tetra Acetic Acid (EDTA) was used as anti-coagulant. Blood profiles were measured to determine the health status of livestock and blood parameters measured were hemoglobin levels, the number of red blood cells and white blood cells, packed cell volume/ hematocrit, and differentiation of white blood cells and calculation of types of white blood cells using the techniques of Pampori and Iqbal [9]. A counting chamber was used to count the $\mathrm{RBC}$ and $\mathrm{WBC}$. The percentage of haemoglobin was measured by using $0.1 \mathrm{~N} \mathrm{HCl}$ and distilled water that converted the haemoglobin into acid haematin.

\subsection{Differential counts}

Differential counts determination was conducted by using blood smear. Staining protocol used was Wright-Giemsa as described by Samour and Howlett [10]. A-200 leukocyte was counted per slide. The criteria was based on morphology of types of leukocytes described by Lucas and Jamroz [11].

\subsection{Data Analysis}

Data from all variables were submitted to analysis of variance using SPSS, and adjusted means were compared by the Duncan's Multiple Range Test, at less than 0.05 of probability.

\section{RESULTS AND DISCUSSION}

\subsection{Microclimate}

The environment temperature and relative humidity were fluctuated during the transportation. Temperature and relative humidity in three consecutive hours of transportation are presented in Table 1.

Table 1. Temperature and humidity during transportation.

\begin{tabular}{|c|c|c|}
\hline Time & $\begin{array}{c}\text { Temperature } \\
\left({ }^{(} \mathrm{C}\right)\end{array}$ & Humidity (\%) \\
\hline $11 \mathrm{am}$. & 35.9 & 60.25 \\
\hline $12 \mathrm{pm}$. & 34.7 & 61 \\
\hline $13 \mathrm{pm}$. & 33.5 & 64 \\
\hline
\end{tabular}

The ranges of the temperatures and humidity were varied over time. At $11 \mathrm{am}$, the temperature was the highest, but the humidity was the lowest. In contrast, the lowest temperature $(33.5 \mathrm{C})$ and the highest humidity (64\%) was observed at $13 \mathrm{am}$.

In terms of temperature, ranges of temperature in comfort zone of broilers is characterized as 15 to $25^{\circ}$ C [12]. This indicates that the temperature during transportation was above the termoneutral zone. Temperatures of $25^{\circ} \mathrm{C}$ to $35^{\circ} \mathrm{C}$ were classified as critical zone [13]. At this point, the chicken cannot dissipate body heat. Heat loss is through the elimination of respiratory moisture. Kampen et al. [14] explained that ambient temperature over $27.5^{\circ} \mathrm{C}$ leads to alterations in body temperature and respiration.

Evaporation process of broilers generated humidity in the crates. The relative humidity during the transportation were 60.25 to 64 . Optimal relative humidity ranges from 60 to 70 [12]. Thus, the humidity during three different recording time were considered comfort zone. The water vapor resulting from the evaporation process is trapped in the crates so that the humidity of the air increases and even reaches a saturation point [15]. High humidity makes it difficult for chickens to release body heat into the environment.

\subsection{Respiration}

The transportation process is attributable to stress in broiler chickens. Respiratory symptoms are observed along with the presence of stress. This has impacts on physiological responses, body weight loss, and mortality rates. Red dragon fruit peel flour dissolved in drinking water supplementation was 
hypothesized to minimize negative effects of transportation.

The results of the analysis of variance in Table

2 showed that giving red dragon fruit peel flour dissolved into drinking water before transportation had no significant effect on respiration rate $(\mathrm{P}>0.05)$.

Table 2. Effect of red dragon fruit peel flour supplementation on respiration rate of broiler chickens.

\begin{tabular}{|c|c|c|c|c|c|}
\hline \multirow{2}{*}{$\begin{array}{c}\text { Observation } \\
\text { period }\end{array}$} & \multicolumn{4}{|c|}{ Respiration rate time/min (average \pm SD) } & \multirow{2}{*}{$\mathrm{P}$} \\
\cline { 2 - 5 } & $\mathrm{P} 0$ & $\mathrm{P} 1$ & $\mathrm{P} 2$ & $\mathrm{P} 3$ & \multirow{2}{*}{0.218} \\
\hline $\begin{array}{c}\text { 0 hour } \\
\text { Transportation }\end{array}$ & $51.73 \pm 10.69$ & $54.53 \pm 8.57$ & $58.67 \pm 8.44$ & $54.67 \pm 7.84$ & 0.504 \\
\hline $\begin{array}{c}3 \text { hours } \\
\text { Transportation }\end{array}$ & $64.7 \pm 7.81$ & $69.47 \pm 12.01$ & $66.67 \pm 9.76$ & $69.07 \pm 11.80$ & 0.04 \\
\hline
\end{tabular}

Different superscript letters show significant differences at $\mathrm{p}<0.05$ P: Probability, SD: Standard deviation, P0: control, P1: 2.43 grams of red dragon fruit peel flour, P2: 3.64 grams of red dragon fruit peel flour, P3: 4.86 grams of red dragon fruit peel flour

Supplementation of bioactive compound such as vitamin $\mathrm{E}, \mathrm{C}$ and selenium are reported functional to fight heat stress. Red dragon fruit peel contains higher antioxidant that the flesh. In normal condition, poultry produces vitamin $\mathrm{C}$ to supply the requirements. However, in stressful condition the demand of vitamin $\mathrm{C}$ is much higher than the vitamin $\mathrm{C}$ produced by adult poultry. Stress transportation due to high temperature, noise dan vibration during the trip might induce stress, which in turn required higher dose of vitamin $\mathrm{C}$. Vitamin $\mathrm{C}$ provided by the red dragon fruit peel flour might be lower than the requirement. In order to meet the vitamin $\mathrm{C}$ requirement during stress transportation, a higher level of red dragon fruit peel flour supplementation is needed.

Transportation process was attributable to changes in respiration rates. Prior the transportation, the broiler chicken had lower respiration rate than those of after a-3 hour transportation. The average respiration rate in broilers ranged from 51.73 to 58.67 times / minute. After a-3 hour transportation, the respiration rate increased to 64.27-69.47 times / minute. According to Abioja et al. [16] the normal respiration rate in broilers is 20-30 times / minute. Increases in respiration rate were induced by high temperature. Temperatures during transportation were classified as critical zone. A prolonged exposure to temperature over $27.5^{\circ} \mathrm{C}$ results in changes in body temperature and respiration [13][14]. Chickens transported in critical zone might have welfare problems. At temperature of $26-35{ }^{\circ} \mathrm{C}$ the frequency of respiration increases known as panting and shows physical tiredness [13]. Body heat loss is through the elimination of respiratory moisture. Panting or respiration at a higher rate is one of most common way to evaporate heat. Interaction of relative humidity and high ambient temperature during transportation led to an increase in respiration rate to evaporate heat. A high ambient temperature induces a decrease in heat production during heat stress. Evaporative heat loss through panting is one of the most effective way to minimize losses [17].

\subsection{Rectal Temperature}

Daylight transportation induced stress due to high temperature. Heat tolerance of chicken during heat stress exposure can be assessed using rectal temperature data [18]. Rectal temperature of broiler chicken under heat stress is presented in Table 2.

Variation in body temperature are related to transport stress [19]. High rectal temperature is an indication of heat stress in broiler chickens during transportation. According to Renaudeau et al. [20], heat stress induced an increase in rectal temperature and weight loss.

The results of the analysis of variance in Table 3 showed that giving red dragon fruit peel flour into drinking water during before transportation had no significant effect $(\mathrm{P}>0.05)$ on rectal temperature. The average rectal temperature in broilers ranged from 40.27 to $40.68{ }^{\circ} \mathrm{C}$. Post a- 3 hour transportation, the rectal temperature increased to $41.11-41.37^{\circ} \mathrm{C}$. According to Abdulqader and Al-fataftah [21], normal rectal temperature in chickens is $40.5-41.5 \mathrm{C}$. Increases in rectal temperature after a-3 hour transportation are in a normal range.

Table 3. Effect of supplementation of red dragon fruit peel flour to drinking water before transportation and after a-3 hour of transportation on the rectal temperature of broilers.

\begin{tabular}{|c|c|c|c|c|c|}
\hline \multirow{2}{*}{$\begin{array}{c}\text { Period of } \\
\text { observation }\end{array}$} & \multicolumn{4}{|c|}{ Rectal temperature ${ }^{\circ} \mathrm{C}$ (average \pm SD) } & \multirow{2}{*}{$\mathrm{P}$} \\
\cline { 2 - 5 } & $\mathrm{P} 0$ & $\mathrm{P} 1$ & $\mathrm{P} 2$ & $\mathrm{P} 3$ & 0.348 \\
\hline $\begin{array}{c}\text { 0 hour } \\
\text { transportation }\end{array}$ & $40.31 \pm 0.93$ & $40.27 \pm 0.62$ & $40.68 \pm 0.67$ & $40.53 \pm 0.56$ & 0.628 \\
\hline $\begin{array}{c}3 \text { hours } \\
\text { Transportation }\end{array}$ & $41.13 \pm 0.62$ & $41.11 \pm 0.83$ & $41.34 \pm 0.63$ & $41.37 \pm 0.61$ & 0.37 \\
\hline
\end{tabular}

Different superscript letters show significant differences at p <0.05 P: Probability, SD: Standard deviation, P0: control, P1: 2.43 grams of red dragon fruit peel flour, P2: 3.64 grams of red dragon fruit peel flour, P3: 4.86 grams of red dragon fruit peel flour 
High temperature $\left(34-33^{\circ} \mathrm{C}\right)$ with relative humidity of $64-60 \%$ induced evaporative heat loss. Active evaporative heat loss or panting seemed effective to balance heat production and heat loss during daylight transportation when relative humidity was not too high. As a result, rectal temperature could be maintained close to $41.0^{\circ} \mathrm{C}$.

\subsection{Effects of transportation on body weight loss}

Heat stress may occur during commercial transportation. Heat stress transportation causes body weight loss. Data of the broiler chicken weight loss after three hours transportation are displayed in Table 4.

Table 4. Effect of supplementation of red dragon fruit peel flour to drinking water before 3 hours of transportation on body weight loss of broiler chickens

\begin{tabular}{|c|c|c|c|c|c|}
\hline \multirow{2}{*}{$\begin{array}{c}\text { Measurement } \\
\text { period }\end{array}$} & \multicolumn{4}{|c|}{ Body weight loss $(\mathrm{Kg})$ (average \pm SD $)$} & \multirow{2}{*}{$\mathrm{P}$} \\
\cline { 2 - 5 } & $\mathrm{P} 0$ & $\mathrm{P} 1$ & $\mathrm{P} 2$ & $\mathrm{P} 3$ & 0.322 \\
\hline $\begin{array}{c}3 \text { hours } \\
\text { transportation }\end{array}$ & $0.11 \pm 0.08$ & $0.16 \pm 0.19$ & $0.09 \pm 0.05$ & $0.13 \pm 0.07$ & 0.07 \\
\hline
\end{tabular}

Different superscript letters show significant differences at $\mathrm{p}<0.05$ P: Probability, SD: Standard deviation, P0: control, P1: 2.43 grams of red dragon fruit peel flour, P2: 3.64 grams of red dragon fruit peel flour, P3: 4.86 grams of red dragon fruit peel flour

\subsection{Percentage of body weight loss}

Tabel 5. Effect of supplementation of red dragon fruit peel flour supplementation on percentage of body weight loss

\begin{tabular}{|c|c|c|c|c|c|}
\hline \multirow{2}{*}{$\begin{array}{c}\text { Measurement } \\
\text { period }\end{array}$} & \multicolumn{4}{|c|}{ Percentage of body weight loss (average \pm SD) } & \multirow{2}{*}{$\mathrm{P}$} \\
\cline { 2 - 5 } & $\mathrm{P} 0$ & $\mathrm{P} 1$ & $\mathrm{P} 2$ & $\mathrm{P} 3$ & \\
\hline $\begin{array}{c}3 \text { hours } \\
\text { transportation }\end{array}$ & $0.06 \pm 0.04$ & $0.08 \pm 0.08$ & $0.05 \pm 0.03$ & $0.07 \pm 0.04$ & 0.360 \\
\hline
\end{tabular}

Different superscript letters show significant differences at $\mathrm{p}<0.05$ P: Probability, SD: Standard deviation, P0: control, P1: 2.43 grams of red dragon fruit peel flour, P2: 3.64 grams of red dragon fruit peel flour, P3: 4.86 grams of red dragon fruit peel flour

The results showed that giving red dragon fruit peel flour into drinking water after 3 hours of transportation had no significant effect on percentage of weight loss $(\mathrm{P}>$.0.05). The average percentage of broiler body weight loss ranged from $0.05-0.08 \%$. Weight loss in open transportation system is due to interaction of broilers with extreme outside environment. Solar heat radiation that was received directly by broilers triggers excessive heat stress, which affected the performance of broilers [25]. Feed reserves were used to produce heat. Similarly, muscle activity during panting also used energy. Both heat production and heat loss required energy, which was supplied from the feed reserves in the body; thus, body weight decreased [26].

\subsection{Death on arrival}

There are contributing factors that lead to stress transportation such as improper handling methods, high temperature and humidity, noise dan vibration. These may induce chronic stress and dead. Dead on arrival observed during the study is presented in Table 5.

Tabel 6. Effect of dragon fruit peel flour supplementation on mortality rate

\begin{tabular}{|c|c|c|c|c|c|}
\hline $\begin{array}{c}\text { Measurement } \\
\text { period }\end{array}$ & \multicolumn{4}{|c|}{ Mortality rate (average \pm SD) } & P \\
\cline { 2 - 6 } & $\mathrm{P} 0$ & $\mathrm{P} 1$ & $\mathrm{P} 2$ & $\mathrm{P} 3$ & \\
\hline $\begin{array}{c}3 \text { hour } \\
\text { transportation }\end{array}$ & $6.67 \pm 25.82$ & $6.67 \pm 25.82$ & $0.00 \pm 0.00$ & $0.00 \pm 0.00$ & 0.576 \\
\hline
\end{tabular}

Different superscript letters show significant differences at $\mathrm{p}<0.05$ P: Probability, SD: Standard deviation, P0: control, P1: 2.43 grams of red dragon fruit peel flour, P2: 3.64 grams of red dragon fruit peel flour, P3: 4.86 grams of red dragon fruit peel flour. 
Supplementation of red dragon fruit peel prior transportation did not affect mortality rate ( $\mathrm{P}>0.05 \%)$. Vošmerová et al. [27] mentioned that the transportation process could affect the death factor caused by temperature. The birds cope with high environmental temperature by increasing heat loss through heavy panting. Eventhough heavy panting evaporates heat, it also increases load of muscle activity, and energy depletion occurs. An extended period of heat exposure reduces ability of transported animal to cope with the situation and the animals died.

\subsection{Hematology}

Potential bioactive compounds as antioxidants in red dragon fruit peel include vitamin $\mathrm{C}$, carotenoids, vitamin E, vitamin B, flavonoids, and polyphenols [28]. Vitamin $\mathrm{C}$ is one type of secondary antioxidant that is widely used for the health of the body. Effects of red dragon fruit peel supplementation on blood profile are displayed in Table 6 .

\subsection{Red Blood Cells}

The application of red dragon fruit peel flour dissolved in drinking water has no significant effect on red blood cells count of broiler chickens subjected to transportation stress $(\mathrm{P}>0.05)$. The number of broiler red blood cells in this study was in normal range. Average range of broiler red blood cells during the study ranged from 2.58 million / $\mu 1-2.72$ million / $\mu$ l. According to [29], the normal number of broiler red blood cells is 2.47 million / $\mu 1-3$ million / $\mu 1$. Thus, the number of red blood cells is still in the normal range.

\subsection{White Blood Cells}

Red dragon fruit peel supplementation did not affect white blood cells count as presented in Table 6 . However, the figure reached the upper limit (31.060 40.960 cells/ $\mu$ l blood). The number of white blood cells in healthy chickens are 20,700 - 30,000 [30,31]. This indicates that open transportation created a stressful environment to the broilers.

Some studies reported that vitamin $\mathrm{C}$ reduces stress metabolic signs at level supplementation of 250 $\mathrm{mg} / \mathrm{kg}$. Supplementation of red dragon fruit peel flour in this study may be below the requirement. A feasible approach to determine the levels of red dragon fruit peel flour supplementation is by calculating the content of its vitamin $C$. Insufficient vitamin $C$ supplementation is not able to minimize the stress transportation.

\subsection{Hemoglobin blood cell count}

Provision of red dragon fruit peel flour had no significant effect on the hemoglobin of broiler chickens subjected to stress transportation $(\mathrm{P}>0.05)$. Table 3 shows that broiler chickens supplemented with red dragon fruit peel flour have an average hemoglobin ranging from $6.98-9.80 \%$, and these figures are classified normal.

It is worth noting that hemoglobin in red dragon fruit peel groups had higher concentrations of hemoglobin. Hemoglobin is a major oxygen transporter protein. There are mechanisms of endogenous antioxidant genes expression that is related to hemoglobin concentration. Flavanoid plays important role to activate nuclear factor erythroid 2 related factor 2 (Nrf2) that leads to an increase in endogenous antioxidant genes expression. The presence of Nrf2 improves adaptability of cells to oxidative stress [32], and it is responsible for body's iron homeostasis through heme synthesis, catabolism of hemoglobin, iron depository and iron transport [33]. At a higherlevel supplementation, red dragon fruit peel supplementation may contribute body's iron homeostasis and to cope with rapid increase in oxygen transport by hemoglobin under heat stress.

Table 7. Effects of red dragon fruit peel supplementation on blood profiles

\begin{tabular}{|l|l|l|l|l|l|}
\hline \multirow{2}{*}{\multicolumn{1}{c|}{ Blood profile }} & \multicolumn{5}{c|}{ Average concentration \pm SD } \\
\cline { 2 - 7 } & \multicolumn{1}{c|}{$\mathrm{P} 0$} & \multicolumn{1}{c|}{$\mathrm{P} 1$} & $\mathrm{P} 2$ & $\mathrm{P} 3$ & $\mathrm{P}$ \\
\hline Red blood cells $\left(10^{6} / \mu 1\right)$ & $2.68 \pm 0.13$ & $2.62 \pm 0.16$ & $2.58 \pm 0.11$ & $2.72 \pm 0.16$ & 0.448 \\
\hline White blood cells $\left(10^{3} / \mu 1\right)$ & $36.06 \pm 9.72$ & $31.06 \pm 7.49$ & $37.28 \pm 5.83$ & $40.96 \pm 8.90$ & 0.315 \\
\hline Hemoglobin $(\mathrm{g} \%)$ & $6.98 \pm 0.98$ & $8.68 \pm 1.45$ & $9.44 \pm 1.04$ & $9.80 \pm 1.14$ & 0.366 \\
\hline Hematokrit $(\%)$ & $25.90 \pm 5.02$ & $25.35 \pm 2.43$ & $26.36 \pm 3.83$ & $24.48 \pm 2.61$ & 0.912 \\
\hline
\end{tabular}

Different superscript letters show significant differences at p <0.05 P: Probability, SD: Standard deviation, P0: control, P1: 2.43 grams of red dragon fruit peel flour, P2: 3.64 grams of red dragon fruit peel flour, P3: 4.86 grams of red dragon fruit peel flour.

\subsection{Hematocrit}

Similar with other blood parameters, hematocrit or packed cell volume of broilers was not affected by red dragon fruit peel flour supplementation $(\mathrm{P}>0.05)$. The range of the average number of broilers' hematocrit in this study ranged from $24.48-26.36 \%$. According to [34], normal hematocrit values in broilers range from 24-43\%. Moura et al. [35] stated that the number of erythrocytes and the hematocrit value run parallel to each other, and changes in hematocrit value has an important effect on the blood's ability to carry oxygen. Changes in the mean number of hematocrit, seem to have the same pattern as the mean number of red blood cells, this is understandable because the hematocrit is a percentage of the red blood cells themselves. 


\subsection{Leukocyte}

Leukocyte responses during stress road transportation in broilers given red dragon fruit peel flour are presented in Table 8. In general, supplementation of dragon fruit peel flour in chicken subjected to road transportation did not affect leukocyte differential count $\mathrm{P}>0.05$ ).

Table 8. Effect of red dragon fruit peel flour supplementation on leukocyte differential count. of broiler subjected to road transportation

\begin{tabular}{|l|c|c|c|c|c|}
\hline \multirow{2}{*}{$\begin{array}{l}\text { Leukocyte } \\
\text { differential count }\end{array}$} & \multicolumn{5}{|c|}{ (Average \pm SD) } \\
\cline { 2 - 6 } & P0 & P1 & P2 & P3 & P \\
\hline Limfosit (\%) & $44.40 \pm 5.55$ & $49.40 \pm 4.39$ & $51.40 \pm 6.11$ & $48.40 \pm 5.55$ & 0.261 \\
\hline Heterofil (\%) & $36.60 \pm 5.90$ & $34.80 \pm 3.27$ & $34.20 \pm 5.72$ & $34.80 \pm 4.44$ & 0.881 \\
\hline Eosinofil (\%) & $6.00 \pm 3.16$ & $5.60 \pm 3.65$ & $5.00 \pm 4.36$ & $5.70 \pm 2.59$ & 0.950 \\
\hline Basofil (\%) & $0.40 \pm 0.55$ & $0.00 \pm 0.00$ & $0.00 \pm 0.00$ & $0.00 \pm 0.00$ & 0.083 \\
\hline Monosit (\%) & $11.20 \pm 3.49$ & $8.60 \pm 3.29$ & $7.60 \pm 1.67$ & $7.40 \pm 2.07$ & 0.150 \\
\hline Ratio H/L (\%) & $0.84 \pm 0.21$ & $0.71 \pm 0.11$ & $0.68 \pm 0.17$ & $0.73 \pm 0.17$ & 0.470 \\
\hline
\end{tabular}

Different superscript letters show significant differences at $\mathrm{p}<0.05$ P: Probability, SD: Standard deviation, P0: control, P1: 2.43 grams of red dragon fruit peel flour, P2: 3.64 grams of red dragon fruit peel flour, P3: 4.86 grams of red dragon fruit peel flour

The supplementation of red dragon fruit peel flour supplementation did not affect the leukocyte count and leukocyte differential count as well as the heterophils and lymphocyte ratio. However, all of the broiler chickens subjected to transportation stress showed signs of stress. Temperature during transportation fell into the category above the comfort zone, and heat stress occurred. Heat stress is detrimental to homeostasis, and it interferes adrenalcorticoid axis. Moreover, the increase in environmental temperature induced glucocorticoid production, which trigger a decrease in lymphocyte production (leukopenia) due to the shrinkage of the thymus lymphoid organ weight and the fabrication bursa [36]. The range of broiler lymphocyte counts during the study was 44.40 to 51.40. [37] [38] reported that lymphocyte of broiler chicken kept in $23^{\circ} \mathrm{C}$ ranges from $78 \%$ to $90 \%$. This is in agreement [39] results that mentioned stress leads to a decrease in the number of lymphocytes and increase in the number of heterophils thus the heterophiles and lymphocytes ratio $(\mathrm{H}: \mathrm{L})$ increased. The average range of the $\mathrm{H} / \mathrm{L}$ ratio of broiler chickens was 0.68 to $0.84 \%$. Ratio between heterophils and lymphocytes of broilers in normal conditions is $0.45-0.5 \%$ [39]. Chicken corresponds to high temperature during transportation with an increase in $\mathrm{H} / \mathrm{L}$ ratio and in leukocyte count. Data indicates that the broilers were under heat stress. The level of dragon fruit peel flour supplementation does not meet the requirement to combat stress. A higher level of supplementation is needed.

\section{CONCLUSION}

Based on the results of the study it can be concluded that giving red dragon fruit peel flour dissolved into drinking water at the levels of $2.43 \mathrm{~g} /$ head, $3.64 \mathrm{~g} /$ head, $4.86 \mathrm{~g} /$ head has no significant effect $(\mathrm{P}>0.05)$ on physiological responses, weight loss, mortality rate, blood profile, leucocyte differentiation, and $\mathrm{H} / \mathrm{L}$ ratio. All of the broilers are under heat stress.

\section{REFERENCES}

[1] G. Jayaprakash, M. Sathiyabarathi, M. A. Robert, and T. Tamilmani,. "Transportation Stress in Broiler Chicken", International Journal of Science, Environment and Technology, vol. 5, no. 2, pp. 806 - 809, 2016.

[2] K. Elrom, "Handling and transportation of broilers; welfare, stress, fear and meat quality; Part V: Transport to the slaughter house", Israel J. of Vet. Med, vol. 56, pp. 1-3, 2000.

[3] E. Delezie, Q. Swennen, J. Buyse, and E. Decuypere, The Effect of Feed Withdrawal and Crating Density in Transit on Metabolism and Meat Quality of Broilers at Slaughter Weight, Poultry Sci, vol. 86, no. 7, pp. 1414-1423, 2000.

[4] N. P. Caffreya, I. R. Dohoob, M.S. Cockram, "Factors affecting mortality risk during transportation of broiler chickens for slaughter in Atlantic Canada, Preventive" Veterinary Medicine, vol. 147, no. 1, pp. 199-208, 2017.

[5] H. R. Trunkfield, and D.M. Broom, "The Walfare of Calves During Handling and Transport", Aplied Animal Behavioural Science, vol. 28, pp. $135-152,1990$.

[6] I. Zulkifli, M.T.C. Norma, C.H. Chong, T.C. Loh, "Heterophil to lymphocyte ratio and tonic immobility reactions to preslaughter handling in 
broiler chickens treated with ascorbic acid", Poultry Sci, vol. 79, no. 30, pp. 402-406, 2000.

[7] R. Nurliyana, I. Syed Zahir, K. M. Suleiman, M.R. Aisyah, "Antioxidant study of pulps and peels of dragon fruits: A comparative study", International Food Research Journal, vol. 17, no. 2, pp. 367-375, 2010.

[8] W.S. Choo, and W.K. Yong, "Antioxidant properties of two species of Hylocereus fruits", Advances in Applied Science Res, vol. 2, no. 3, pp. 418-425, 2011.

[9] Z. A. Pampori, and S. Iqbal, "Haematology, serum chemistry and electrocardiographic evaluation in native chicken of Kashmir", Int. J. Poult. Sci, vol. 6, no. 8, pp. 578-582, 2007.

[10] J. Samour and J. Howlett, "Hematology Analyses", Chapter 3, in: SAMOUR , J. (Ed) Avian Medicine, 2nd edition, Mosby Elsevier, London. pp. 46-48, 2008.

[11] A.M. Lucas, and C. Jamroz, "Atlas Avian Hematology”, Monograph 25. USDA, Washington DC, 1961.

[12] A.R. El-Boushy and A.R. Van Marle, "The Effects of Climate on Poultry Physiology in Tropics and Their Improvements", World Poultry Sci. J, vol. 34, pp. 155-17, 1978.

[13] A.Youssef, V. Exadaktilos, D.A. Berckmans, "Towards real-time control of chicken activity in a ventilated chamber", Biosyst. Eng, vol. 135, Pp. 31-43, 2015.

[14] M. Van Kampen, B. W. Mitchell, and H. S. Siegel, Influence of sudden temperature changes on oxygen consumption and heart rate in chickens in light and dark environments, The Journal of Agricultural Science, vol. 90, no. 3, pp. $605-$ 609, 2009.

[15] M. Heinonen, M. Anagnostou, S. Bell, M. Stevens, Investigation of the equivalence of national dewpoint temperature realizations in the $-50 \mathrm{C}$ to +20 $\mathrm{C}$ range, International Journal of Thermophysics, vol. 33, Pp. 1422-1437, 2012.

[16] O.O. Olukomaiya, O.A. Adeyemi, O.M. Sogunle, M.O. Abioja and I.A. Ogunsola, Effect of Feed Restriction and Ascorbic Acid Supplementation on Growth, Performance, Rectal Temperature and Respiratory Rate of Broiler Chicken, The Journal of Animal \& Plant Sciences, vol. 25, no. 1, pp. 65-71, 2015.

[17] S. Yahav, D. Shinder, J. Tanny, S. Cohen, Sensible heat loss: the broiler's paradox, World's Poultry Science Journal, vol. 61, no. 3, Pp. 419 - 434, 2005.

[18] J.Y. Hu, P.Y. Hester, M.M. Makagon, Y. Xiong, R.S. Gates, H.W. Cheng, Effect of cooled perches on physiological parameters of caged White Leghorn hens exposed to cyclic heat, Poultry Science. vol. 98, no. 6, pp. 2317-2325, 2019.

[19] I. Zulkifli, A.F. Akmal, A. F. Soleimani, M. A. Hossain, E. A. Awad, Effects of low-protein diets on acute phase proteins and heat shock protein 70 responses, and growth performance in broiler chickens under heat stress condition, Poultry Science, vol. 97, pp. 1306-1314, 2018.
[20] D.Renaudeau, A.Collin, S.Yahav, V.de Basilio,J.L.Gourdine, R.J.Collier, Adaptation to hot climate and strategies to alleviate heat stress in livestock production, Animal, vol. 6, no. 5, pp.707-728, 2012.

[21] A. Abdelqader, A.R. Al-Fataftah, Thermal acclimation of broiler birds by intermittent heat exposure, Journal of Thermal Biology, vol. 39. pp. 1-5 2014.

[22] B. Moritz, A. E. Schmitz, A.L.S. Rodriguez, A.L.D. Mauricio, P.Cunha, Reviews: Current Topics, The role of vitamin $\mathrm{C}$ in stress-related disorders, The Journal of Nutritional Biochemistry. vol. 85, no.10, pp. 84-59, 2020.

[23] A. S. del Barrio, W. D. Mansilla, A. NavarroVilla, J. H. Mica, J. H. Smeets, L. A. den Hartog, A.I.García-Ruiz, Effect of mineral and vitamin C mix on growth performance and blood corticosterone concentrations in heat-stressed broilers, Journal of Applied Poultry Research vol. 29, no.1, pp. 23-33, 2020.

[24] Z. H. Song, K. Cheng, X. C. Zheng, H.Ahmad, L. L. Zhang, T.Wang, Effects of dietary supplementation with enzymatically treated Artemisia annua on growth performance, intestinal morphology, digestive enzyme activities, immunity, and antioxidant capacity of heat-stressed broilers, Poultry Science, vol. 97, no. 2 , pp. $430-437$

[25] M. Saeed, G. Abbas, M. Alagawany, A. A. Kamboh, M.E. A. El-Hack, A.F..Khafaga, S. Chao, Heat stress management in poultry farms: A comprehensive overview, Journal of Thermal Biology vol. 84, pp. 414-425, 2019.

[26] S. Syafwan, R. Kwakkel, M.W.A.Verstegen, Heat Stress and feeding strategies in meat-type chickens, World's Poultry Science Journal, vol. 67, no. 04 pp.653 - 674, 2011.

[27] P. Vošmerová, I. Bedanova, P. Chloupek, J. Chloupek, Jr. J.Suchý, V.Večerek, Transportinduced Changes in Selected Biochemical Indices in Broilers as Affected by Ambient Temperatures, Acta Veterinaria Brno, vol.79, no. 9, pp. S41-S46, 2010.

[28] F. Le Bellec, F. Vaillant, and E. Imbert, Pitaya (Hylocereus spp.): a new fruit crop, a marker with a future, Journal of Fruit, vol. 6, pp. 237-250, 2006.

[29] C.C. Chernecky, B.J. Berger, Laboratory Tests and Diagnostic Procedures, Elsevier Health Sciences (06-14), ISBN 978-1416066835, 2007.

[30] N. Ghane, A. Vard, A.Talebi, P. Nematollahi, Segmentation of White Blood Cells From Microscopic Images Using a Novel Combination of K-Means Clustering and Modified Watershed Algorithm, Journal of Medical Signals and Sensors, vol. 7, no. 2, pp. 92-101, 2017.

[31] W.O. Reece, M.J. Swenson, The composition and functions of blood. In: Reece WO (ed) Dukes'physiology of domesticanimals, 12th edn. Comstock Publishing Associates, Ithaca, pp. 2652, 2004.

[32] Saha, D., S. Koli, K.V.R. Reddy, Transcriptional regulation of $\mathrm{Hb}-\alpha$ and $\mathrm{Hb}-\beta$ through nuclear factor E2-related factor-2 (Nrf2) activation in human vaginal cells: A novel mechanism of 
cellular adaptability to oxidative stress, Am J Reprod Immunol. vol..77, no. 6, 2017.

[33] M.J. Kerins, and A. Ooi, The Roles of NRF2 in Modulating Cellular Iron Homeostasis. Antioxid Redox Signal. vol. 29, no. 17, pp.1756-1773, 2018.

[34] In ovo injection of ascorbic acid and higher incubation temperature modulate blood parameters in response to heat exposure in broilers, Br Poult Sci. vol. 60, no. 3, pp. 279-287, 2019.

[35] AS. Moura, M.C. Ledur, C. Boschiero, LF Nones Pinto, Jaenisch Burt DW, Coutinho LL Quantitative trait loci with sex-specific effects for internal organs weights and hematocrit FR,value in a broiler-layer cross. J Appl Genet. vol. 57, no. 2, pp. 215-224. 2016.

[36] Siegel, H.S. 1995. Stress, strain and resistence. Brit. Poultry Sci, vol. 36 pp. 3-22, 1995.
[37] U. Cahyaningsih, Y. Kondo, A. Abe, A. Tanabe, The diurnal rhythms in lymphocyte counts and antibody formation in Chicks, Japanese Poultry Science, vol. 27, no. 1, pp. 29-37, 1990.

[38] H.K. Makeri, J.O. Ayo, T. Aluwong, and N.S Minka, Daily Rhythms of Blood Parameters in Broiler Chickens Reared under Tropical Climate Conditions, J Circadian Rhythms 155. (2017) doi: $10.5334 /$ jcr. 151

[39] W Aengwanich, P. Sridama, Y. Phasuk, T.Vongpralab, P. Pakdee, S. Katawatin and S. Simaraks, Effects of ascorbic acid on cell mediated, humoral immune response and pathophysiology of white blood cell in broilers under heat stress. Songklanakarin J. Sci. Technol, vol. 25, no. 3, pp. 297-305, 2003. 